\title{
Pendugaan Umur Simpan Benih Padi (Oryza sativa L) Menggunakan Metode ASLT (Accelerated Shelf Life Testing) dengan Pendekatan Model Kadar Air Kritis
}

\section{Estimation shelf life of rice seeds (Oryza sativa L) using the ASLT (Accelerated Shelf Life Testing) method with a critical moisture content approach}

\author{
I Putu Mas Pradnyana Wibawa, Ida Bagus Putu Gunadnya, I Made Anom Sutrisna Wijaya \\ Program Studi Teknik Pertanian, Fakultas Teknologi Pertanian, Unud \\ E-mail: pradnyanawibawa95@gmail.com
}

\begin{abstract}
Abstrak
Tujuan dari dilakukanya penelitian Ini adalah untuk menduga umur simpan benih padi menggunakan metode ASLT (Accelerrated Shelf Life Testing) dengan pendekatan model kadar air kritis. Adapun benih yang digunakan adalah benih varietas Ciherang dan varietas Inpari 30. Kemasan dari benih padi adalah plastic jenis Polipropilen (PP). Benih padi disimpan pada kondisi lingkungan (suhu 290C dan RH 75\%). Pengamatan benih dianggap kritis ketika persentase daya berkecambah di bawah $80 \%$. Ditemukan dari hasil pengukuran bahwa nilai permeabilitas kemasan $(\mathrm{k} / \mathrm{x})$ dari plastic $\mathrm{PP}$ adalah $0,013 \mathrm{gH} 2 \mathrm{O} / \mathrm{m} 2$.day.mmHg. Pengamtan kadar air awal (Ma) adalah $13 \%$, kadar air kritis (Mc) adalah $29 \%$, total padatanya (WS) adalah $8,8 \mathrm{~kg}$, dan perbedaan tekanan $(\Delta \mathrm{P}) 1,15 \mathrm{mmHg}$. Sementara Inpari 30 memiliki nilai kadar air awal (Ma) 14\%, kadar air kritis 29\%, total padatannya (WS) 8,7 kg, dan $\Delta \mathrm{P} 0,9$ $\mathrm{mmHg}$. Dari nilai tersebut dapat diduga umur simpan dua varietas benih bersertifikat yang dikemas dalam plastik PP dan disimpan pada suhu 29oC dan RH 75\% adalah 156 hari $(5,03$ bulan) untuk varietas Ciherang dan 254 hari ( 8,19 bulan) untuk 30 varietas Inpari.
\end{abstract}

Kata Kunci: Umur Simpan, metode ASLT, kadar air kritis, polipropilen.

\begin{abstract}
The purpose of this study was to prediction the shelf life of certified rice seeds using the ASLT (Accelerated Shelf Life Testing) method based on the critical moisture content approach. The varieties of rice seeds used in this research were Ciherang and Inpari 30 varieties which packed with polypropylene (PP) plastic packaging. The rice seeds packages were stored at environmental condition (temperature of $29^{\circ} \mathrm{C}$ and $\mathrm{RH}$ of $75 \%$ ). Observation on seeds germination was done daily until the seeds have a germination percentage below $80 \%$. When the seeds under this condition, moisture content of the seeds was measured and refer as critical moisture content. It was found that the packaging permeability $(\mathrm{k} / \mathrm{x})$ of PP plastic was $0.013 \mathrm{~g}$ $\mathrm{H} 2 \mathrm{O} / \mathrm{m}^{2}$.day. $\mathrm{mmHg}$. Observation on rice seed of Ciherang variety revealed that its values of initial moisture content (Ma) was $0.133 \%$, its critical moisture content $(\mathrm{Mc})$ was $0.291 \%$, its total solid (Ws) was $8.8 \mathrm{~kg}$, and pressure difference $(\Delta \mathrm{P})$ was $1,15 \mathrm{mmHg}$. While, for Invary 30 variety the values of its shelf life parameters were as follows: Ma $0.144 \%$, Mc $0.293 \%$, Ws $8.7 \mathrm{~kg}$, and $\triangle \mathrm{P} 0.9 \mathrm{mmHg}$. The prediction of shelf life the two certified rice seeds which were packed in PP plastic and stored at $29 \mathrm{oC}$ and $\mathrm{RH}$ of $75 \%$ were 156 days (5.03 months) for Ciherang variety and 254 days (8.19 months). ) for Inpari 30 variety.
\end{abstract}

Keywords: Shelf life, rice seeds, ASLT method, critical moisture content, polypropilen.

\section{PENDAHULUAN}

Benih padi menjadi aspek yang sangat penting dalam pertanian khususnya pertanian tanaman pangan, sehingga kondisi perbenihan mencerminkan kemajuan pertanian dalam suatu negara. Semakin maju teknologi pertanian, semakin maju pula perkembangan teknologi benih. Keadaan ini akan bertambah baik apabila ketersediaan benih padi berkualitas sebagai unsur utama dalam kegiatan peningkatan produksi mencukupi (Arsanti, 1995).

Penurunan mutu pada benih akan berjalan selama penyimpanan dan tidak dapat dihentikan tetapi dapat diperlambat dengan mengatur kondisi penyimpanan. Kadar air adalah faktor utama pendugaan masa simpan benih dan rusaknya benih selama 
penyimpanan sebagian besar dipengaruhi oleh air dalam benih (Justice dan Bass, 2002).

Di pasar sudah tersedia benih padi dari beberapa varietas unggul yang ditangkar oleh badan usaha milik negara. Selama penyimpanan dan pemasaran, benih padi unggul dikemas menggunakan kemasan plastik jenis Polypropylen. Pada kemasan tidak dicantumkan masa aman edar benih padi, sehingga diperlukan pendugaan umur simpan benih padi dalam label kemasan plastik.

Pendugaan umur simpan dapat dilakukan dengan metode Extended Storage Study (ESS) dan Accelerated Shelf-life Testing (ASLT). Pendugaan umur simpan dengan metode Extended Storage Study (ESS) yaitu menyimpan produk pangan pada kondisi sebenarnya, cara ini dapat menghasilkan pendugaan yang paling tepat namun waktu dan biaya yang diperlukan lebih besar. Dengan metode Accelerated Shelf-life Testing (ASLT) pendugaan umur simpan dapat dipercepat, mudah, murah dan mendekati umur simpan yang sebenarnya. Adapun pendugaan umur simpan dengan metode ASLT dilakukan dengan cara menyimpan produk pada lingkungan dan kondisi yang menyebabkan produk mengalami kerusakan. Data nilai mutu selama penyimpanan diubah dalam bentuk model matematika, kemudian umur simpan diduga dengan cara ekstrapolasi persamaan pada kondisi penyimpanan normal. Metode percepatan dapat dilakukan dalam waktu yang lebih singkat dengan akurasi yang baik. Metode ASLT yang sering digunakan adalah model Arrhenius dan model kadar air kritis (Kusnandar, 2012).

\section{METODE PENELITIAN}

\section{Tempat dan Waktu Penelitian}

Penelitian ini dilaksanakan di Laboratorium Teknik Pascapanen Fakultas Teknologi Pertanian Universitas Udayana. Penelitian ini dilaksanakan pada bulan September 2018. Suhu yang digunakan pada penelitian ini adalah suhu ruang $29^{\circ} \mathrm{C}$ dengan kelembaban $75 \%$.

\section{Bahan dan Alat Penelitian}

Bahan-bahan yang digunakan dalam penelitian ini adalah benih padi produksi PT. Pertani (Persero) UPB Desa Munggu. Dua varietas benih yang dipakai dalam penelitian ini yaitu Ciherang, dan Inpari 30. Bahan lain yang digunakan adalah larutan $\mathrm{NaCl}$, kemasan plastik PP ketebalan $0.14 \mathrm{~mm}$, aquades, kertas buram, dan silica gel.

Alat-alat yang akan digunakan yaitu cawan, penyangga, neraca analitik (merek Sartorius 4 desimal), toples plastik, gelas ukur, termometer, $a_{w}$ meter (merek Aqualab PRE Measurement range $\left(a_{\mathrm{w}}\right)$
: 0.05-1.000), Oven Labo (Model Do: 2110, Suhu $\left.10^{\circ} \mathrm{C}-300^{\circ} \mathrm{C}\right)$.

\section{Pelaksanaan Penelitian}

Pendugaan umur simpan benih padi menggunakan metode ASLT dengan pendekatan model kadar air kritis ini menggunakan langkah-langkah sebagai berikut: Persiapan sampel benih padi 2 varietas beserta alat dan bahan lainnya, penentuan permeabilitas uap air kemasan, penyimpanan pada kelembaban tinggi agar cepat terjadinya peningkatan kadar air yang memicu kerusakan pada benih padi, pengukuran parameter mutu benih padi, penentuan parameter kerusakan visual benih padi.

\section{Tahapan Penelitian}

Tahapan dalam Pendugaan Umur Simpan Benih Padi Dengan Metode ASLT (Accelerated Shelf Life Testing) dengan Pendekatan Kadar Air Kritis Penentuan Umur Simpan dengan metode ASLT (Accelerated Shelf Life Testing) dilakukan dengan beberapa tahapan yaitu penghitungan kadar air awal (Ma), Penghitungan kadar air kritis (Mc) yang diperoleh dengan terlebih dahulu menyimpan benih pada kondisi RH tinggi dengan menggunakan larutan garam jenuh, dan yang terakhir adalah penghitungan parameter pendukung yang terdiri dari permeabilitas kemasan $(\mathrm{k} / \mathrm{x})$, luas permukaan kemasan (A), bobot padatan perkemasan (W/s), dan selisih tekanan uap di luar dan dalam kemasan.

\section{Parameter Pengamatan}

\section{Pengukuran kadar air awal benih (Ma)}

Pengukuran Kadar Air Benih Awal dilakukan dengan cara pemanasan dalam oven, pengukuran kadar air benih dengan cara pemanasan oven merujuk kepada metode International Seed Testing Asociation (ISTA, 2012). Prosedur analisa adalah sebagai berikut: Benih padi yang telah berupa serbuk atau bahan yang telah dihaluskan sebanyak 4,5 g dalam wadah dikeringkan dalam oven dengan suhu $1330 \mathrm{C}$ selama 2 jam 6 menit lalu di dinginkan dalam desikator 45 menit dan ditimbang lalu dipanaskan sampai dicapai berat konstan. Pengurangan berat merupakan banyaknya air dalam bahan. Perhitungan kadar air berdasarkan berat kering adalah sebagai berikut :

K.air $=($ Berat awal - berat akhir $) /($ Berat awal $) \mathrm{x}$ $100 \%$

\section{Kadar Air Kritis Benih Padi (Mc)}

Penentuan kadar air kritis dilakukan setelah benih sudah memperoleh perlakuan berupa benih padi disimpan pada kondisi kelembaban tinggi. Pengamatan persentase daya perkecambahan dilakukan setiap hari selama 6 hari. Saat daya 
berkecambah benih di bawah $80 \%$ maka dianggap benih sudah tidak layak. Lalu dilakukan pengukuran kadar air benih tersebut dan ditetapkan sebagai kadar air kritisnya, analisa pengukuran kadar air merujuk pada metode ISTA tahun 2012.

\section{Penentuan Presentase Daya Perkecambahan Benih Padi}

Pengamatan presentase daya perkecambahan dilakukan setiap hari selama 6 hari. Tata cara penetapan daya perkecambahan dilakukan dengan metode ISTA tahun 2012 dimana benih padi dikecambahkan pada media kertas buram masingmasing sample varietas terdiri atas tiga kali pengulangan sampai dicapai kondisi kritis.

\section{Penentuan Konstanta Permeabilitas Uap Air} $(\mathbf{K} / \mathbf{x})$

Penentuan permeabilitas kemasan digunakan desikan berupa silica gel. Silica gel dimasukkan kedalam kemasan yang akan ditentukan permeabilitasnya terhadap uap air. Silica gel sebanyak 20 gram yang telah dikemas kemudian dimasukkan ke dalam toples tertutup yang berisi larutan jenuh $\mathrm{NaCl}$. Penentuan permeabilitas kemasan dilakukan pada suhu dan $\mathrm{RH}$ ruang. Penimbangan dilakukan setiap hari sampe diperoleh berat konstan. Kemudian dibuat grafik dengan berat total silica gel dan kemasan sebagai sumbu Y dan waktu pengamatan sebagai sumbu X. Dari grafik tersebut akan diketahui diperoleh slope $(\Delta \mathrm{W} / \Delta \theta)$. Perhitungan permeabilitas kemasan dilakukan dengan menggunakan persamaan berikut ini.

$\mathrm{k} / \mathrm{x}=(\Delta \mathrm{W} / \Delta \theta) /($ A.Pout $)$

Keterangan : $\mathrm{k} / \mathrm{x}=$ Permeabilitas kemasan (gH2O/hari/m2.mmHg)

$\begin{array}{ll}\Delta \mathrm{W} / \Delta \theta & =\text { Slope }(\mathrm{gH} 2 \mathrm{O} / \mathrm{hari}) \\ \mathrm{A} & =\text { luas kemasan }(\mathrm{m} 2) \\ \text { Pout } & =\text { tekanan uap air pada suhu }\end{array}$ penyimpanan $(\mathrm{mmHg})$

\section{Penentuan Luas Permukaan (A)}

Penentuan luas permukaan dilakukan dengan cara mengukur Panjang dan lebar kemasan plastic yang digunakan dan dilanjutkan dengan perhitungan dengan rumus sebagai berikut:

Luas Permukaan $(\mathrm{A})=\mathrm{P} \times \mathrm{L}$ x 2

\section{Berat padatan (WS)}

Bobot sampel perkemasan diperoleh dengan bobot per kemasan masing-masing varietas benih dan kadar air awal (Ma) benih padi.

Bobot air $=$ Bobot benih padi $(\mathrm{g}) \mathrm{x}$ kadar air awal (gH2O/g padatan) (4)

Bobot Padatan (Ws) = Bobot benih padi (gram) bobot air (gram Air)

\section{Selisih tekanan udara diluar dan di dalam kemasan $(\Delta P)$}

Selisih tekanan udara luar dan dalam kemasan adalah perbandingan antara RH ruang dan Aw dari benih padi.

8. Pendugaan umur simpan benih padi metode ASLT dengan pendekatan kadar air kritis.

Dari parameter diatas dilanjutkan dengan memasukan parameter kedalam persamaan berikut :

Keterangan :

$$
\mathrm{t}=(((\mathrm{Mc}-\mathrm{Ma}) \mathrm{Ws}) /((\mathrm{k} / \mathrm{x})(\mathrm{A})(\Delta \mathrm{P})))
$$

$\mathrm{t}=$ umur simpan produk (hari)

$\mathrm{Ma}=$ kadar air awal produk (g H2O/g padatan)

$\mathrm{Mc} \quad=$ kadar air kritis produk (g H2O/g padatan)

$\mathrm{k} / \mathrm{x}=$ konstanta permeabilitas uap air kemasan $(\mathrm{g} / \mathrm{m} 2$. hari.mmHg$)$

A $\quad=$ luas permukaan kemasan $(\mathrm{m} 2)$

Ws = berat padatan produk awal $(\mathrm{g})$

$\Delta \mathrm{P} \quad=$ selisih antara tekanan udara di luar ketika produk disimpan (lingkungan) atau Pout dan tekanan udara di dalam kemasan atau Pin $(\mathrm{mmHg})$

\section{HASIL DAN PEMBAHASAN}

\section{Pengolahan Benih Padi di PT. Pertani Pertani (Persero)}

Benih yang di ambil adalah benih varietas Ciherang, dan Inpari 30 sebanyak $5 \mathrm{~kg}$ untuk masing-masing varietas. Benih yang diambil adalah benih yang telah melewati tahap penjemuran dan pensortiran dengan mesin blower atau yang disebut Calon Benih Kering Bersih (CBKB). Tata cara proses penjemuran benih padi dilakukan pada landasan jemur dengan luas 1584 $\mathrm{m} 2$ dengan kapasitas 60 ton untuk sekali penjemuran dengan lama jemur 3 hari sampai 4 hari tergantung pada cuaca. Benih yang sudah dijemur tadi dilanjutkan dengan proses pensortiran menggunakan mesin. Mesin Blower berfungsi untuk pembersihan dan memisahkan calon benih dari kotoran fisik berupa jerami, gabah hampa, kerikil, tanah, biji gulma, biji tanaman lain dan kotoran fisik lainya. Mesin Blower ini menggunakan dinamo penggerak yang berkekuatan $22000 \mathrm{~W}$ atau setara $30 \mathrm{HP}$.

\section{Kondisi Benih Awal}

Dari pengujian kadar air awal sample benih Ciherang dan Inpari 30. Pada kondisi awal sebelum percepatan penyimpanan benih padi memiliki basis basah sebesar $0.118 \mathrm{gH}_{2} \mathrm{O} / \mathrm{g}$ varietas Ciherang, dan 0.126 $\mathrm{gH}_{2} \mathrm{O} / \mathrm{g}$ varietas Inpari 30. Diperoleh basis kering 13 \% varietas Ciherang, dan $14 \%$ varietas Inpari 30 untuk daya kecambah masing-masing varietas benih padi $99 \%$ untuk varietas Ciherang, dan $98 \%$ untuk varietas Inpari 30 . Untuk nilai $\mathrm{a}_{\mathrm{w}}$ meter pada varietas Ciherang dan Inpari masing-masing menunjukan nilai 0.703 aw dan $0.721 \mathrm{a}_{\mathrm{w}}$. Berdasarkan (Rasminah, 
2010) Kadar air optimum dalam penyimpanan bagi sebagian besar benih padi adalah antara $13 \%-14 \%$, dengan kelembaban relatif udara sekitar $70 \%-75 \%$ dan suhu $27^{\circ}-32^{\circ} \mathrm{C}$. Kadar air benih merupakan salah satu faktor penting yang mempengaruhi daya simpan benih. Jika kadar air benih terlalu tinggi, benih dapat memanas karena respirasi dan berbagai cendawan dapat tumbuh. Karena itu, sangat penting untuk menjamin agar benih yang dipanen memiliki kadar air yang aman sebelum disimpan. Pertanaman benih hampir selalu dipotong ketika kadar air benih lebih tinggi dari pada yang diinginkan jika benih akan disimpan dengan aman. Menurut (Mugnisjah dan Setiawan, 2001) Kadar air benih yang aman bervariasi menurut benih, tetapi umumnya $14 \%$ atau kurang dianggap memuaskan dalam penyimpanan jangka pendek dan $10 \%$ atau kurang jika benih akan disimpan beberapa bulan.

\section{Penurunan mutu benih padi ditinjau dari kadar} air dan daya berkecambahnya

Dalam menentukan nilai kadar air kritis atau mutu akhir dari benih padi, dilakukan penyimpanan benih padi pada kondisi sangat lembab dengan RH $75 \%$. Setiap hari dilakukan pengukuran nilai kadar air dari benih padi beserta uji daya perkecambahan benih padi masing-masing varietas sampai diperoleh presentase daya perkecambahan dibawah $80 \%$. Untuk masingmasing varietas dari hasil pengujian benih varietas Ciherang dan Inpari mengalami kerusakan di hari ke 5 dengan presentase daya berkecambah untuk varietas Ciherang 77\% dan Inpari 30 79\%.

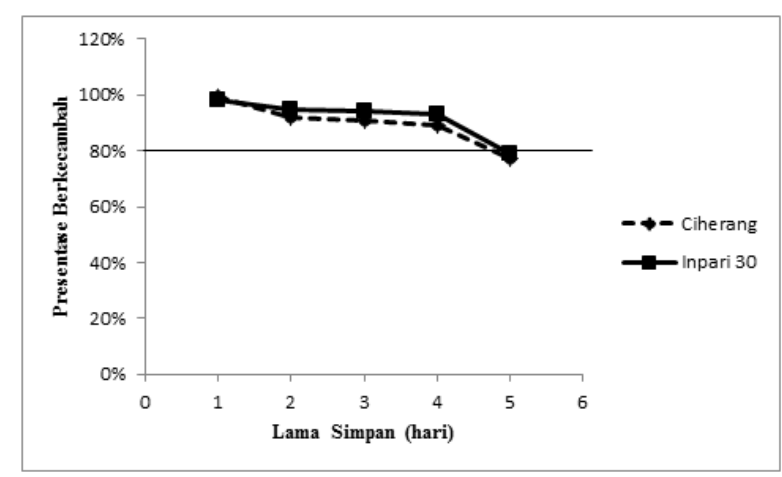

Gambar 1. Penurunan daya berkecambah benih padi varietas Ciherang dan Inpari 30 menurut persentase perkecambahan dan lama simpan.

Pada tabel 2 dan tabel 3 dapat dilihat penurunan daya berkecambah benih varietas Ciherang dan Inpari 30. Kerusakan yang terjadi pada benih padi ditandai dengan pertumbuhan jamur disekitar kulit benih dan benih mengalami perubahan volume nya menjadi agak lunak ini disebabkan karena pada saat kondisi lembab proses penyerapan dari air ke benih sangat cepat yang menyebabkan terjadi proses respirasi. Respirasi merupakan proses katabolisme atau penguraian senyawa organik menjadi senyawa anorganik. Proses respirasi merombak glukosa dan menghasilkan $\mathrm{CO}_{2}$ serta energi (Andhi et al., 2012). Proses respirasi menimbulkan peningkatan suhu yang berlangsung secara perlahan, panas hasil respirasi memengaruhi kondisi benih pada penyimpanan, dimana dapat menimbulkan kerusakan pada benih yang disimpan.

\section{Kadar air Kritis (Mc) Benih Padi Varietas Ciherang, dan Inpari 30}

Pengujian kadar air kritis dilakukan untuk mengetahui kandungan kadar air kritis yang terdapat pada sample benih. Selama penyimpanan penyerapan air dari RH lembab kandungan garam jenuh tidak membuat benih berkecambah saat proses penyimpanan karena benih padi ortodok yang digunakan tidak toleran pada salinitas tinggi tetapi berkecambah normal saat dilakukan uji perkecambahan. Sampel pada masing-masing varietas benih padi dinyatakan rusak apabila sample memilki daya berkecambah dibawah $80 \%$. Menurut International Seed Testing Asociation (ISTA, 2012) terdapat lima kriteria benih yaitu benih normal, benih abnormal, benih keras, benih segar dan mati. Dari pengamatan yang dilakukan sebagian besar benih yang tidak tumbuh karena benih tersebut mati dan ditemukan juga beberapa benih yang abnormal tetapi tumbuh baik ketika perkecambahan diperpanjang. Benih yang mati adalah benih yang tidak bertumbuh setelah proses berkecambah dianggap selesai atau berakhir yang ditandai dengan volume benih tampak berubah serta bila dipegang agak lunak bahkan kadang-kadang ditumbuhi jamur, berarti benih telah mengalami deteriorasi lanjut (mati) (Saenong et al.,1988). Presentasi daya kecambah saat benih mencapai kadar air kritis yang diperoleh dari hasil uji ISTA menunjukan hasil sebagai berikut untuk benih varietas Ciherang sebesar $77 \%$ dan benih varietas Inpari 30 sebesar 79\% dari hasil tersebut diperoleh untuk masing-masing varietas kadar air kritis basis basah nya sebagai berikut: varietas Ciherang 0.226 $\mathrm{gH} 2 \mathrm{O} / \mathrm{g}$ padatan , dan varietas Inpari $0.227 \mathrm{gH} 2 \mathrm{O} / \mathrm{g}$ padatan. Kadar air kritis basis kering varietas Ciherang 29\% padatan, dan varietas Inpari $3029 \%$ padatan. Nilai kadar air kritis yang diperoleh dipertimbangkan penggunaanya dalam perhitungan umur simpan benih padi. Pada gambar 3 dan 4 ditampilkan kenaikan kadar air benih selama penyimpanan pada kondisi lingkungan lembab peningkatan kadar air mencapai setimbang dihari ke 6 dimana benih tak lagi mengalami peningkatan kadar air. 


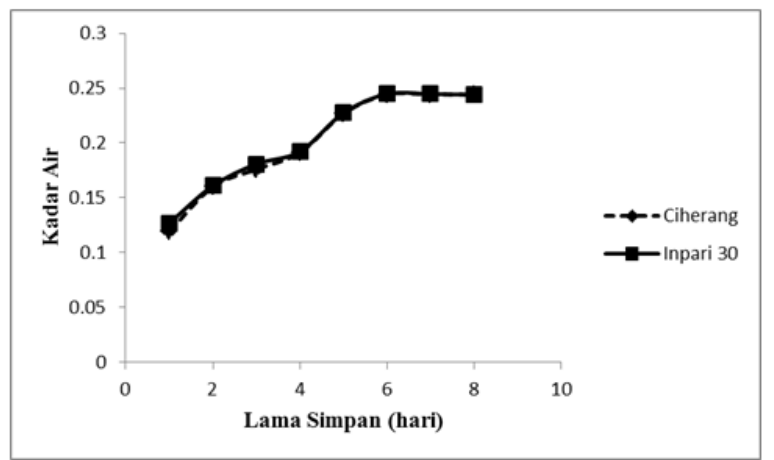

Gambar 2. Peningkatan kadar air selama penyimpanan pada $\mathrm{RH}$ tinggi varietas Ciherang dan varietas Inpari 30.

\section{Permeabilitas Kemasan $(\mathbf{k} / \mathbf{x})$}

Permeabilitas uap air kemasan pada benih padi perlu diketahui untuk menentukan umur simpan. Kemasan yang memiliki fungsi utama pelindung benih dari uap air. Selain itu pengemasan pada benih bertujuan untuk menurunkan interaksi langsung benih dengan lingkungan yang mengakibatkan cepat meningkatnya kadar air benih padi dan mempengaruhi tingkat deteriorasi (kerusakan/kemunduran) benih. Jenis kemasan yang digunakan pada pengemasan benih padi adalah plastic jenis PP (Polipropilen) dengan tebal $0.14 \mathrm{~mm}$ berasal dari monomer propilena yang diperoleh dari pemurnian minyak bumi. PP merupakan jenis bahan baku plastik yang ringan dengan densitas 0.90-0.92 memiliki kekerasan dan kerapuhan yang sangat tinggi dan bersifat kurang stabil terhadap panas dikarenakan mengandung hidrogen tersier. Penggunaan bahan pengisi dan penguat memungkinkan plastik PP memiliki mutu kimia yang baik sebagai bahan polimer dan tahan terhadap pemecahan yang ditimbulkan oleh tekanan (stress-cracking) walaupun diletakan pada suhu tinggi.

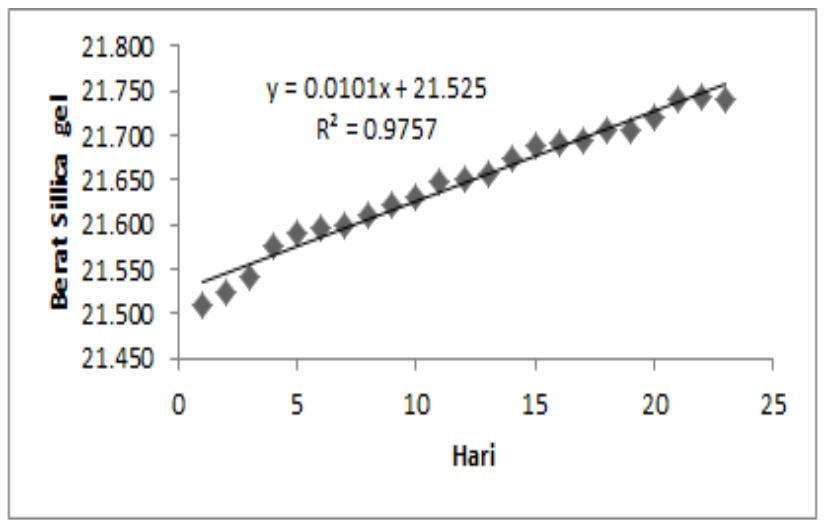

Gambar 3. Kenaikan berat silica gel pada penyimpanan $\mathrm{RH}$ tinggi.

Plastik polipropilen merupakan plastik yang baik sebagai barrier terhadap uap air pada benih, hal ini disebabkan karena jenis plastik ini memiliki permeabilitas uap air yang rendah. Pada hasil penelitian diperoleh pertambahan berat pada silica gel yang disimpan pada $\mathrm{RH} 75 \%$ dengan ketebalan plastik $0.14 \mathrm{~mm}$ sebagai berikut.

Kemasan yang saat ini digunakan oleh para penangkar dan produsen benih padi untuk menyimpan benih adalah kemasan plastik Polipropilen sangat mirip dengan polietilen dan sifatsifat penggunaannya juga serupa (Brody, 1972). Polipropilen lebih kuat dan ringan dengan daya tembus uap yang rendah, ketahanan yang baik terhadap lemak, stabil terhadap suhu tinggi dan cukup mengkilap (Winarno dan Jenie, 1983). Pada desikan, pertambahan berat setiap harinya mengalami kenaikan. Hal ini terjadi karena semakin lama masa penyimpanan, semakin banyak uap air yang diserap oleh desikan dan menjaga agar tekanan uap air tetap rendah. Berdasarkan hasil tersebut dapat dibuat kurva regresi linier untuk memperoleh nilai kemiringan titik hubungan antara berat silica gel/ hari. Titik-titik hubungan antara silica gel kesetimbangan $\backslash$ memiliki persamaan linier $\mathrm{y}=\mathrm{a}+\mathrm{bx}$. Nilai a pada persamaan tersebut merupakan slope $(\Delta \mathrm{W} / \Delta \theta)$. Pada gambar menghasilkan persamaan garis $\mathrm{y}=0.0101 \mathrm{x}+21.525$ dengan $\mathrm{R}^{2}=0.9757$. berdasarkan persamaan tersebut diperoleh nilai slope 0.0101 .

Benih Padi PT. Pertani Persero sebagai sampel memiliki kemasan dengan kapasitas $10 \mathrm{~kg}$ yang meliputi panjang kemasan $59.5 \mathrm{~cm}$ dan lebar kemasan $40.7 \mathrm{~cm}$ sehingga luas permukaan kemasan yang diperoleh adalah :

Luas Permukaan $(\mathrm{A}) \quad=$ Panjang $\mathrm{x}$ Lebar $\mathrm{x} 2$

$$
\begin{aligned}
& =0.595 \mathrm{~m} \times 0.407 \mathrm{~m} \\
& =0,48433 \mathrm{~m}^{2}
\end{aligned}
$$

Nilai Tekanan Uap diluar dan dalam kemasan (Po) Benih Padi pada penelitian ini menggunakan data sekunder yang diambil dari tabel uap (Labuza, 1982) Suhu yang digunakan selama penyimpanan yaitu berkisar antara $28-30^{\circ} \mathrm{C}$, rata-rata suhu ruangan penyimpanan yaitu $29^{\circ} \mathrm{C}$. Nilai tekanan uap murni pada suhu $29^{\circ} \mathrm{C}$ berdasarkan tabel uap air Labuza (1982) yaitu sebesar $30.043 \mathrm{mmHg}$.

Perhitungan permeabilitas kemasan dilakukan dengan menggunakan (persamaan 2) berikut ini.

$$
\begin{gathered}
\frac{\mathrm{k}}{\mathrm{x}}=\frac{\Delta \mathrm{W} / \Delta \theta}{\mathrm{A} \cdot \text { Pout }} \\
\frac{\mathrm{k}}{\mathrm{x}}=\frac{0.0101}{0.48433 \times 1.5} \\
0.013 \mathrm{gH}_{2} \mathrm{O} / \mathrm{hari} / \mathrm{m}^{2} \cdot \mathrm{mmHg}
\end{gathered}
$$

Menurut Astuti Setyowati (2015) jenis plastik PP dengan ketebalan $0.14 \mathrm{~mm}$ memiliki nilai 
permeabilitas sebesar $0.0111 \mathrm{gH}_{2} \mathrm{O} / \mathrm{hari} / \mathrm{m}^{2} . \mathrm{mmHg}$. Ukuran tebal film mempengaruhi jumlah ikatan silang pada plastik. Plastik yang tebal memiliki jumlah ikatan silang yang lebih banyak dibanding plastik yang tipis sehingga jarak tempuh uap air untuk berdifusi dari dan kedalam kemasan akan semakin panjang, dengan demikian laju perpindahan uap air menjadi kecil. Semakin kecil angka permeabilitasnya maka kemasan tersebut semakin baik untuk dijadikan pengemas, karena memiliki ketahanan terhadap uap air dibanding dengan kemasan yang memiliki angka permeabilitas yang lebih besar (Suparmo, 1997).

Selisih tekanan udara diluar dan di dalam kemasan $(\Delta P)$

Selisih tekanan $(\Delta \mathrm{P})$ antara produk pangan dalam kaitanya benih padi dengan lingkungan akan menyebabkan proses difusi uap air dari produk pangan ke lingkungan atau sebaliknya ditinjau dari nilai $a_{\mathrm{w}}$ produk pangan dalam kaitanya benih padi. Selisih tekanan udara di dalam kemasan ditentukan berdasarkan nilai $a_{w}$ produk pangan dan $R H$ penyimpanan pada suhu tertentu. Besarnya nilai tekanan di luar (Pout) dan tekanan di dalam (Pin) dipengaruhi oleh besaran tekanan uap air murni pada suhu terukur (Po). Suhu penyimpanan yang digunakan sebesar $29^{\circ} \mathrm{C}$, kemudian diketahui nilai aw sebesar 0,70 untuk varietas ciherang dan 0.72 untuk varietas inpari 30 tekanan uap air murni pada suhu $29^{\circ} \mathrm{C}$ berdasarkan tabel uap air adalah 30,042 $\mathrm{mmHg}$ (Labuza,1982). Dari data tersebut diperoleh perbedaan tekanan $(\Delta \mathrm{P})$ masing-masing sebesar 1.5 mmHg untuk varietas Ciherang dan 0.9 mmHg untuk varietas Inpari 30.

\section{Berat Padatan Awal (Ws)}

Bobot sampel perkemasan diperoleh dengan bobot per kemasan $10 \mathrm{~kg}$ masing-masing varietas benih dan kadar air awal (Mi) benih padi, bobot yang diperoleh yaitu :

Bobot benih padi (w) x kadar air awal $\left(\mathrm{gH}_{2} \mathrm{O} / \mathrm{g}\right.$ padatan)

Bobot padatan perkemasan Ciherang $=8800.71$ gram Bobot padatan perkemasan Inpari 30 $=8730.3$ gram

\section{Umur Simpan Benih Padi Metode ASLT \\ (Accelerated Shelf Life Testing)}

Persamaan Labuza Termodifikasi dapat mengintegrasikan unsur permeabilitas kemasan, berat kering benih, luas bahan pengemas, dan selisih antara tekanan udara di luar ketika produk disimpan (lingkungan) atau dan tekanan udara di dalam kemasan.

Tabel 1. Parameter perhitungan umur simpan benih padi

\section{Parameter}

\section{Nilai}

Kadar air awal basis kering (Mi) Benih Padi Ciherang $\mathrm{gH}_{2} \mathrm{O} / \mathrm{g}$ solid.

Kadar air awal basis kering (Mi) Benih Padi Inpari $\mathrm{gH}_{2} \mathrm{O} / \mathrm{g}$ solid.

Kadar air kritis basis kering (Mi) Benih Padi Ciherang (\%)

Kadar air kritis basis kering (Mi) Benih Padi Inpari 30 (\%).

Permeabilitas kemasan $(\mathrm{k} / \mathrm{x}) \mathrm{gH}_{2} \mathrm{O} / \mathrm{hari} / \mathrm{m}^{2}$. $\mathrm{mmHg}$.

Luas Permukaan Kemasan (A) $\mathrm{m}^{2}$.

Bobot Sample perkemasan benih ciherang (Ws) kg

Bobot Sample perkemasan benih Inpari (Ws) kg

Selisih tekanan udara luar dalam $\Delta \mathrm{P}$ benih Ciherang $\mathrm{mmHg}$

Nilai-nilai yang diperoleh kemudian diintegrasikan

$$
t=\frac{(M c-M a) W s}{\left(\frac{k}{x}\right)(A)(\Delta P)}
$$

Varietas Ciherang

$$
t=\frac{(0.291(\text { gH20 } / \text { g padatan })-0.133(\text { gH20 } / \text { g padatan })) 8.8(\text { kg padatan })}{\left(0.013 \mathrm{gH} 20 / \text { hari } / \mathrm{m}^{2} . \mathrm{mmHg}\right)\left(0.48433 \mathrm{~m}^{2}\right)(1.5 \mathrm{mmHg})}
$$

$\mathrm{t}=1.37144 / 0.008756333$ 


$$
\begin{aligned}
& \mathrm{t}=156.6 \text { hari } \\
& \mathrm{t}=5.03 \text { bulan } \\
& \text { Varietas Inpari } 30 \\
& \mathrm{t}=\frac{(0.293(\mathrm{gH} 20 / \text { g padatan })-0.144(\mathrm{gH} 20 / \text { g padatan })) 8.7(\mathrm{~kg} \text { padatan })}{\left(0.013 \mathrm{gH} 20 / \text { hari } / \mathrm{m}^{2} \cdot \mathrm{mmHg}\right)\left(0.48433 \mathrm{~m}^{2}\right)(0.9 \mathrm{mmHg})} \\
& \mathrm{t}=1.292128 / 0.005078673 \\
& \mathrm{t}=254.4 \text { hari } \\
& \mathrm{t}=8.19 \text { bulan }
\end{aligned}
$$

Benih varietas inpari memiliki umur simpan lebih lama 3 bulan dibandingkan benih varietas ciherang ini disebabkan karena perbedaan ketebalan kulit sekam. Menurut Badan Penelitian dan Pengembangan Pertanian (2018) benih padi varietas ciherang menghasilkan rata-rata $16 \mathrm{~kg}$ sekam dari $100 \mathrm{~kg}$ giling kering panen sedangkan benih padi varietas Inpari 30 menghasilkan rata-rata $17 \mathrm{~kg}$ sekam dari $100 \mathrm{~kg}$ giling kering panen ini mengindikasikan bahwa volume sekam benih inpari 30 lebih berat (tebal) sehingga perbedaan permeabilitas pada sekam menjadi faktor penting dalam perbedaan umur simpan.

\section{KESIMPULAN DAN SARAN}

\section{Kesimpulan}

Dari hasil dan pembahasan umur simpan benih padi Varietas Ciherang dan Inpari 30 yang telah dilakukan dapat disimpulkan bahwa penurunan mutu benih padi varietas Ciherang dan Inpari 30 terjadi saat kadar air masing-masing varietas berada di angka 0.291 $\mathrm{gH}_{2} \mathrm{O} / \mathrm{g}$ varietas Ciherang, dan $0.293 \mathrm{gH}_{2} \mathrm{O} / \mathrm{g}$ varietas Inpari 30 dengan presentase daya berkecambah benih varietas Ciherang sebesar $77 \%$ dan benih varietas Inpari 30 sebesar 79\%. Hasil dari penentuan umur simpan benih padi varietas Ciherang dan Inpari 30 dengan menggunakan metode ASLT pendekatan kadar air kritis menunjukan bahwa benih padi Varietas Ciherang dan Inpari30 yang dikemas menggunakan plastik Polypropylen memiliki umur simpan masing-masing 156 hari (5.03 bulan) untuk varietas Ciherang dan 254 hari (8.19 bulan) untuk Varietas Inpari 30 apabila disimpan pada RH $75 \%$. Hal ini menunjukan bahwa perbedaan masa simpan sangat besar dipengaruhi oleh ketebalan kemasan jadi perlu dibuat ketebalan kemasan yang berbeda pada setiap masing-masing varietas.

\section{Saran}

Untuk memperpanjang masa simpan benih varietas Ciherang dapat digunakan plastik dengan jenis yang sama dan ukuran yang lebih tebal.

\section{DAFTAR PUSTAKA}

Andhi, T.C., A. Purwantoro, dan P. Yudono, 2012. Studi Aspek Fisiologis Dan Biokimia Perkecambahan Benih Jagung (Zea Mays L.) pada Umur Penyimpanan Benih yang berbedaVegetalika 1(3):120-130.

Arsanti, I.W. 1995. Analisis Produksi dan Strategi Pemasaran Benih. Fakultas Pertanian. Institut Pertanian Bogor, Bogor.

Astuti, S. 2015. Kondisi Kritis dan Umur Simpan Oyek Berprotein Tinggi yang Dikemas dalam Polipropilen dan Polietilen. Fakultas Agroindustri. Universitas Mercu Buana Yogyakarta, Yogyakarta.

Balitbangtan. 2018. Sekam Padi dari Limbah Jadi Bahan Bakar Alternatif. Badan Penelitian dan Pengembangan Pertanian. Jawa Tengah.

Brody A.L. 1972, Aseptic packaging of foods. Food Technology. Aug. 70-74.

ISTA. 2012. International rules for seed testing. Seed Science and Technology. 27:163-164.

Justice, O.L., dan L.N. Bass. 2002. Prinsip dan Praktek Penyimpanan Benih. Jakarta: PT. Raga Grafindo Persada.

Kusnandar, F. 2012. Pendugaan umur simpan produk pangan dengan metode accelerated self-life testing. http://www.foodreview.biz. Diakses tanggal: 8 Agustus 2018.

Labuza T.P. 1982. Open Shelf-Life Dating of Foods. Food Science and Nutrition. Press Inc., Westport. Connecticut.

Rasminah, S. 2010. Penyakit-Penyakit Pasca Panen Tanaman Pangan. UB Press. Malang.

Saenong, S. 1988. Teknologi dan sistem pembenihan tanaman pangan. Risalah Simposium Penelitian Tanaman Pangan. Badan 
Penelitian dan Pengembangan Pertanian, Puslitbang Tanaman Pangan Ciloto. Ciloto H. 415-432.

Surpamo. 1997. Permeabilitas Film Plastik dan Laminasi. Pusat Antar Unversitas Pangan dan Gizi, Universitas Gajah Mada.Yogyakarta.

Winarno, F.G., dan B.S.L. Jenie. 1983. Kerusakan Bahan Pangan dan Cara Pencegahannya. Jakarta. Ghalia Indonesia. 275. 